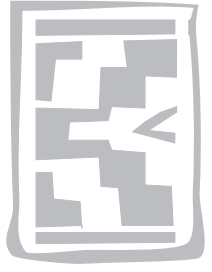

\title{
Bovine intestinal cellular responses following primary and challenge infections with Calicophoron microbothrium metacercariae
}

\author{
M. MAVENYENGWA ${ }^{1}$, S. MUKARATIRWA ${ }^{3 *}$, M. OBWOLO $^{1}$ and J. MONRAD ${ }^{2}$
}

\begin{abstract}
MAVENYENGWA, M., MUKARATIRWA, S., OBWOLO, M. \& MONRAD, J. 2008. Bovine intestinal cellular responses following primary and challenge infections with Calicophoron microbothrium metacercariae. Onderstepoort Journal of Veterinary Research, 75:109-120

This study was carried out to establish whether cattle can develop resistance to re-infection by Calicophoron microbothrium by assessing the response of intestinal mucosal globule leukocytes, eosinophils, mast cells and basophils, and the establishment of the parasite in the host. A total of 24 1-yearold Tuli steers were randomly divided into four groups of six animals each and infected with $C$. microbothrium metacercariae. On the first day of the study, animals in Groups I and II were immunized with 5000 metacercariae and then challenged with 15000 metacercariae on Day 150 postimmunization. Animals in Group III were immunized with 15000 metacercariae at the same time that Groups I and II animals were challenged to act as a positive control group. Animals in Group IV were left uninfected and acted as a negative control group. Three animals from each group were slaughtered on Day 28 post-challenge and the remainder were slaughtered on Day 42 post-challenge. The established amphistomes were recovered and histopathological and cytological examinations were done on the jejunum, duodenum, abomasum and the rumen. The establishment rates of the challenge infection in the immunized and challenged groups were lower and ranged from 0 to $0.2 \%$ as compared to $6 \%$ from naive animals infected as positive controls. Animals immunized and then challenged with $C$. microbothrium had significantly higher eosinophil, mast cell and globule leukocytes counts in the intestinal mucosa $(P<0.05)$ as compared to those of the control group. The study indicates that cattle can develop resistance to $C$. microbothrium re-infection and that eosinophils and mast cells may be important cells in the rejection of the parasite.
\end{abstract}

Keywords: Basophil, bovines, Calicophoron microbothrium, challenge, eosinophil, globule leukocyte, mast cell, metacercariae, resistance

\section{INTRODUCTION}

Amphistomosis caused by Calicophoron microbothrium is an infection of cattle, sheep, goats and most wild ruminants and results from the presence of large

* Author to whom correspondence is to be directed. E-mail: mukaratirwa@ukzn.ac.za

1 Faculty of Veterinary Science, Department of Paraclinical Veterinary Studies, University of Zimbabwe, Harare

2 Danish Centre for Experimental Parasitology, Frederiksberg, Copenhagen, Denmark

3 School of Biological and Conservation Sciences, University of KwaZulu-Natal, Westville Campus, Durban 4001

Accepted for publication 17 January 2008-Editor numbers of immature amphistomes in the small intestines of immunologically incompetent hosts (Horak 1967; Dutt 1980; Gupta 1993). The disease is characterized by sporadic epizootics of acute gastroenteritis and loss of production associated with high mortality and morbidity, particularly in young susceptible stock (Butler \& Yeoman 1962; Boray 1969; Horak 1971; Singh \& Lakra 1971; Dutt 1980). After ingestion of herbage contaminated with amphistome metacercariae (Dutt 1980; Boray 1985) the cercariae that excyst in the small intestine cause severe pathology to the mucosa, and after a period move to the rumen where they develop to maturity while living as commensals (Boray 1985; Cheruiyot \& Wamae 1988). 
Clinical amphistomosis has been described in sheep and goats (Mukherjee \& Deorani 1962; Horak \& Clark 1963; Deorani \& Katiyar 1967; Horak 1966, 1967; Rolfe, Boray \& Collins 1994), in water buffaloes (Bulbalus bulbalis) (Panda \& Misra 1980) and cattle (Butler \& Yeoman 1962; Singh \& Lakra 1971; Pillai \& Alikutty 1995). There is growing evidence from both field and experimental observations that sheep, goats and cattle can mount effective resistance to re-infection with amphistomes (Butler \& Yeoman 1962; Horak \& Clark 1963; Horak 1967; Rolfe, Boray, Nichols \& Collins 1991). Cattle have been demonstrated to exhibit stronger resistance to reinfection than sheep (Horak 1967) and use of antihelmintics has been shown to abrogate the acquired immunity in sheep and cattle (Horak 1967). The demonstration of precipitating antibodies and the subsequent successful immunization of both sheep and cattle with irradiated amphistome metacercariae (Horak 1965, 1967; Urvashi \& Kuar 2000) corroborated field and experimental observations that immunity to amphistomes develops with repeated infection.

Gastrointestinal helminth infections in general are characterized by an increase in the number of lymphocytes, mast cells, eosinophils, globule leukocytes and basophils particularly in the intestinal mucosa of sheep (Rothwell \& Dineen 1972; Miller 1984; Huntley, Newlands \& Miller 1984; Huntley 1992; Rothwell, Windon, Horsburgh \& Anderson 1993; Stankiewicz, Jonas, Douch, Rabel, Bisset \& Cabaj 1993; Huntley, Patterson, Mackellar, Jackson, Stevenson \& Coop 1995; Pfeffer, Douch, Shaw, Gatehouse, Rabel, Green, Shirer, Jonas \& Bisset 1996; Winter, Wright \& Lee 1997). The various cells recruited to the site of parasite infection constitute a potent effector system associated with parasite expulsion and the development of resistance (Huntley et al. 1995). Horak (1967) clinically confirmed the occurrence of resistance in cattle repeatedly infected with amphistomes but these studies were conducted without parallel or detailed systematic histopathological examinations of the gastrointestinal tract to establish the cellular effector systems that might be involved in the development of resistance.

A study of the gastrointestinal cellular responses of cattle to challenge with amphistomes could assist in the characterization of the cellular effector systems that might be activated during the development of host resistance to re-infection. Knowledge of such cellular defense systems could be important in predicting the resistance mechanisms associated with bovine amphistomosis and could also assist in the formulation of amphistome control programmes. This study was therefore conducted to identify the cellular effector systems that are recruited after challenge infection in cattle and also to assess anthelmintic effects on established resistance to reinfection.

\section{MATERIALS AND METHODS}

\section{Study site and the selection of experimental animals}

The study was conducted at Grassland Research Station, a government farm in Marondera about $80 \mathrm{~km}$ south-east of Harare, Zimbabwe. The farm is amphistome-free and mainly Tuli cattle are raised there for commercial beef production. It is subdivided into paddocks in which cattle can graze and have access to clean borehole water provided in troughs. Prior to the commencement of the study, faecal samples were collected from 301 -year-old Tuli weaner steers for examination using the sedimentation technique and a modified McMaster technique (Anon 1986) to screen for trematode and nematode infection, respectively. From the parasitefree weaner steers, 24 animals were randomly selected for the study on the basis of age and mass.

The selected animals were allowed to graze in paddocks and had access to clean borehole water in concrete troughs. They were given $10 \%$ fenbendazole every month to control gastrointestinal nematodes.

\section{Identification of Calicophoron microbothrium and production of metacercariae}

Adult Bulinus tropicus naturally infected with $C$. microbothrium were collected from a single natural habitat and maintained under laboratory conditions for periodic shedding of metacercariae. The identity of $C$. microbothrium metacercariae was confirmed through the infection of a single sheep and recovery of mature amphistomes from the rumen for identification. The recovered amphistomes were identified as $C$. microbothrium using the methods described by Eduardo (1983) and Gupta (1993).

For mass production of metacercariae, small nylon gauze bags with an aperture size of $2 \mathrm{~mm}$, each capable of holding 20 snails were used to confine snails during shedding to prevent them ingesting the shed metacercariae. The open end of each snail bag was punched with a stapler and each bag was immersed in individual plastic containers holding 
$500 \mathrm{ml}$ of de-chlorinated pond water. The latter were exposed to direct sunlight for $3 \mathrm{~h}$. The shed cercariae encysted on the water meniscus forming metacercariae. Shedding was induced every 2 days and after each exposure, the snails were taken back into the dark aquaria. The metacercariae were stored in individual plastic containers with de-chlorinated pond water added to just below the band of metacercariae and kept at a temperature of between $24^{\circ} \mathrm{C}$ and $25^{\circ} \mathrm{C}$ for a minimum of 6 days before they were harvested using a fine toothbrush.

\section{Estimation of metacercariae doses for experimental infection}

The number of metacercariae given to each animal were extrapolated from previous pathological studies described by Mavenyengwa (2004), who demonstrated that doses of $C$. microbothrium metacercariae of up to 15000 can cause clinical disease and severe pathological lesions in a bovine intestine. Using this result and also taking into consideration Horak's (1967) hypothesis that, for protective immunity to develop against re-infection in ruminants, the dose of the immunizing metacercariae should be sufficiently high to induce disease in the host. Hence the doses used for the different treatment groups of animals were selected as 5000 metacercariae as the immunizing infection while 15000 metacercariae represented the challenge infection. To estimate the doses for individual animals, metacercariae were brushed from the containers using a soft toothbrush and suspended in water. The number was then estimated by counting metacercariae in several aliquots as described by Rolfe et al. (1994).

\section{Experimental design}

Twenty-four 1-year-old Tuli weaner steers were selected and randomly divided into four groups of six animals each. Groups I, II and III were each infected with a different number of $C$. microbothrium metacercariae at various stages of the study while Group IV was left as an uninfected control (Table 1). Animals in Groups I and II each received an immunizing infection of 5000 metacercariae on the first day of the study by direct inoculation into the rumen with a trocar and canula. On Day 90 post-immunization, and after confirmation of parasite patency, all animals in Group I were dewormed with oxyclozanide (18.7 mg/kg body mass) in combination with levamisole $(9.4 \mathrm{mg} / \mathrm{kg}$ body mass) in two doses, three days apart (Rolfe \& Boray 1987; Anon. 1994). A challenge infection of 15000 metacercariae was then administered to each of the animals in Groups I and II on Day 150 of the study while each animal in Group III received an immunizing infection of 15000 metacercariae to act as a positive control group. Infection was achieved using the same infection techniques as used on Day 1 of the study. Three steers from each group were slaughtered for study during the course of the experiment. Throughout the study the animals were monitored daily for the development of clinical signs until Day 192 when the study was concluded, and all the steers slaughtered for postmortem examination.

\section{Estimation of time intervals for various treatment procedures}

The pathology results described by Mavenyengwa (2004) were used to estimate the time intervals for the administration of the various treatments in this study, as indicated above. Histopathological results (Mavenyengwa 2004) have shown that small numbers of inflammatory cells occur in the gastrointestinal mucosa for up to 3 months post-infection. Therefore, Day 150 post-immunization was considered suitable for the administration of the challenge in-

TABLE 1 Summary of the study design and experimental procedures

\begin{tabular}{|l|l|l|l|l|l|l|}
\hline Group & $\mathbf{N}$ & $\begin{array}{l}\text { MC dose } \\
\text { at primary } \\
\text { infection }\end{array}$ & $\begin{array}{l}\text { Deworming } \\
\text { at } \mathbf{9 0} \text { dpi }\end{array}$ & $\begin{array}{l}\text { MC dose at } \\
\text { challenge } \\
\text { infection (150 dpi) }\end{array}$ & $\begin{array}{l}\text { No. of animals } \\
\text { slaughtered } \\
\text { at 28 dpc }\end{array}$ & $\begin{array}{l}\text { No. of animals } \\
\text { slaughtered } \\
\text { at 42 dpc }\end{array}$ \\
\hline I & 6 & 5000 & + & 15000 & 3 & 3 \\
II & 6 & 5000 & - & 15000 & 3 & 3 \\
III & 6 & 0 & - & 15000 & 3 & 3 \\
IV & 6 & 0 & - & 0 & 3 & 3 \\
\hline
\end{tabular}

$\mathrm{N}=$ Number of animals

$\mathrm{MC}=$ Metacercariae

dpi $=$ Days post-infection

$\mathrm{dpc}=$ Days post-challenge

$+\quad=$ Dewormed

- $\quad$ Not dewormed 
fection on the assumption that complete regeneration of the gut mucosa from the effects of the immunizing infection had taken place.

\section{Sample collection and processing}

Three animals from each group were slaughtered on Day 28 post-challenge infection (Day 178 of the study) while the remaining animals from each group were slaughtered on Day 42 post-challenge infection (Day 192 of the study) in order to collect specimens from the gastrointestinal tract, using standard necropsy techniques. The small intestines of each animal were separated from the rest of the organs with minimal manipulation. Starting from the distal end of the jejunum, $1 \mathrm{~m}$ long small intestinal loops were selected, tied at both ends, cut and placed in labelled plastic containers for fluke recovery. Samples for histopathology were collected from between the loops, rinsed in physiological saline to remove excess faecal material and each segment was preserved in Bouin's fixative. Samples were also taken from the anterior ruminal pillar and the fundus of the abomasum and preserved in Bouin's fixative.

\section{Fluke recovery}

The distribution of flukes along the small intestines was established by scraping the mucosa from the intestinal segments to the level of the muscular tunic with glass slides. The contents of the abomasum, omasum and the reticulum were washed into separate containers and serially sieved under pressure through $2400 \mu \mathrm{m}$ and $850 \mu \mathrm{m}$ sieves, respectively. The mucosal scrapings were similarly sieved and the flukes collected at the bottom of a $10 \ell$ capacity jar. Excess water was decanted and the recovered flukes preserved in $70 \%$ alcohol for identification and counting. The flukes recovered from the immunizing infection were distinguished from those of the challenge infection using body size as a measure, the flukes from the challenge infection being smaller than those from the immunizing infection.

\section{Assessment of the gross pathology of the gut}

The small intestines were subdivided into four anatomical parts, namely the duodenum, the proximal jejunum, the distal jejunum and the ileum. The duodenum extended for $1 \mathrm{~m}$ from the pylorus, the proximal jejunum extended for $3 \mathrm{~m}$ from the distal end of duodenum while the distal jejunum extended for $4 \mathrm{~m}$ from the distal end of the proximal jejunum. The ileum extended from the distal end of the jejunum to the ileo-caecal junction.
To assess the gross pathology of the gut among the different groups of animals, a checklist of gross pathological lesions was developed based on the presence and severity of intestinal wall thickening, mucosal corrugation, hyperaemia, petechiation and ulceration, mucus content and consistency of intestinal contents.

\section{Histology}

Tissue blocks from the samples for histopathological examination were embedded in paraffin wax using conventional techniques.

Triplicate sections, $4 \mu \mathrm{m}$ thick, were cut from each segment of the small intestines, the abomasum and the rumen and each section was stained with haematoxylin and eosin (H\&E), toluidine blue-ferric sulphateferrioxamine B or Giemsa-chromotrope stain. The toluidine blue stain was used to differentiate mast cells, while the Giemsa-chromotrope stain was used to differentiate eosinophils and basophils. The H\&E stain was used to stain globule leukocytes and to evaluate the general histopathology of the various parts.

A checklist of histopathological lesions was also drawn up on the basis of the presence and severity of villous atrophy, cryptal and goblet cell hyperplasia, cystic Brunner's glands, reactive Peyer's patches and fibrous tissue deposition, and the lesions in the various groups of cattle compared.

\section{Cell counting technique}

The villous crypt unit method was used for counting eosinophils, mast cells, basophils and globule leukocytes as described by Miller \& Jarret (1971). For each animal, three intact villous crypt units were identified per intestinal segment and the different cell types counted from the villous tip to the level of the muscularis mucosa. The resultant mean for each cell type represented the cell count per villous crypt unit per segment per animal from which the group mean cell count per intestinal segment was calculated.

\section{Data analysis}

Values for the different cells enumerated were computed using SPSS for Windows (Version 8.0). The means of the cell types were compared among the different treatment groups at various intestinal segments and stages of infection using analysis of variance (ANOVA). Pair-wise comparisons of means were done using the $5 \%$ least significant difference (LSD) method and $P$-values of less or equal to 0.05 were considered significant. 


\section{RESULTS}

\section{Clinical signs}

No clinical signs were observed in any of the animals in all the experimental groups.

\section{Fluke recovery and distribution}

The establishment rates of amphistomes recovered from the different experimental groups are shown in Table 2.

In all the infected animals slaughtered post-challenge, all the flukes were concentrated in the rumen and no flukes were recovered from the duodenum. In Group I, the recovery rate of mature amphistomes from the immunizing infection for individual animals ranged from 7.8 to $84 \%$ while the challenge rates ranged from 0 to $0.8 \%$. The recovery rate of the immunizing infection from the animals in Group II ranged from 2.2 to $39.3 \%$ while the recovery rate for the challenge infection ranged from 0 to $0.7 \%$. The establishment rate for animals in Group III ranged from 0.04 to $6.1 \%$.
In all groups, mature amphistomes from the immunizing infection were found along the anterior pillar of the rumen while the majority of immature amphistomes from the challenge infection were concentrated along the oesophageal groove and a few were present in the reticulum.

\section{Gross pathology of the small intestines}

The gross pathological lesions of the gastrointestinal tract seen in the different treatment groups are presented in Table 3. The lesions were confined to the duodenum and the jejunum in all the infected groups and mainly comprised duodenal thickening and mucosal corrugation. Increased mucus content of the ingesta in both the duodenum and the ileum was also seen. No gross pathological lesions were detected in the duodenum and the jejunum of the control animals slaughtered at the same time.

\section{The gross pathology of the rumen}

Gross pathological lesions of the rumen were observed in three animals (two from Group I and one

TABLE 2 Establishment patterns of Calicophoron microbothrium in the different groups of cattle immunized and challenged with C. microbothrium

\begin{tabular}{|c|c|c|c|c|}
\hline \multirow{3}{*}{ Days post-challenge } & \multirow{3}{*}{ Group } & \multirow{3}{*}{$\mathbf{N}$} & \multicolumn{2}{|l|}{ Establishment } \\
\hline & & & Primary infection & Challenge infection \\
\hline & & & \multicolumn{2}{|l|}{ Recovery (\%) } \\
\hline \multirow{4}{*}{28} & I & 3 & $\begin{array}{r}570(11) \\
4200(84) \\
1311(26)\end{array}$ & $\begin{array}{c}0(0) \\
0(0) \\
12(0.1)\end{array}$ \\
\hline & II & 3 & $\begin{array}{l}112(2.2) \\
202(4) \\
142(3)\end{array}$ & $\begin{array}{c}0(0) \\
24(0.2) \\
0(0)\end{array}$ \\
\hline & III & 3 & 0 & $\begin{array}{c}908(6) \\
6(0.04) \\
540(3.6)\end{array}$ \\
\hline & $\mathrm{IV}^{*}$ & 3 & 0 & 0 \\
\hline \multirow{4}{*}{42} & 1 & 3 & $\begin{array}{c}388(7.8) \\
1901(38) \\
523(10.5)\end{array}$ & $\begin{array}{r}114(1) \\
4(0.03) \\
50(0.33)\end{array}$ \\
\hline & II & 3 & $\begin{array}{l}1967(39) \\
276(6) \\
859(17.2)\end{array}$ & $\begin{array}{l}99(0.7) \\
29(0.2) \\
23(0.2)\end{array}$ \\
\hline & III & 3 & 0 & $\begin{array}{l}529(3.5) \\
425(2.8) \\
200(1.3)\end{array}$ \\
\hline & $\mathrm{IV}^{*}$ & 3 & 0 & 0 \\
\hline
\end{tabular}

* Group IV cattle were uninfected controls 
TABLE 3 Gross pathological lesions of the duodenum and jejunum of the different groups of cattle immunized and challenged with Calicophoron microbothrium

\begin{tabular}{|c|c|c|c|}
\hline Days post-challenge & Group & Intestinal site & Gross pathological lesions \\
\hline \multirow{4}{*}{28} & I & \multirow{4}{*}{$\begin{array}{l}\text { Duodenum and } \\
\text { jejunum }\end{array}$} & $\begin{array}{l}\text { Mild thickening of duodenal wall and corrugation of the mucosa. Height } \\
\text { from muscularis mucosa to tip of mucosal rugae varied from } 6 \mathrm{~mm} \text { in } \\
\text { the proximal duodenum to } 3 \mathrm{~mm} \text { in the distal end. Duodenal and jejunal } \\
\text { contents watery and mixed with mucus. }\end{array}$ \\
\hline & II & & Gross pathological lesions similar to Group I. \\
\hline & III & & $\begin{array}{l}\text { Moderate thickening of the duodenal wall and corrugation of the } \\
\text { mucosa. Height from muscularis mucosa to tip of mucosal rugae varied } \\
\text { from } 8 \mathrm{~mm} \text { in the proximal duodenum to } 3 \mathrm{~mm} \text { in the distal end. } \\
\text { Duodenal and jejunal contents watery and mixed with mucus. }\end{array}$ \\
\hline & $\mathrm{IV}^{*}$ & & No gross pathological lesions observed. \\
\hline \multirow{4}{*}{42} & I & \multirow{4}{*}{$\begin{array}{l}\text { Duodenum and } \\
\text { jejunum }\end{array}$} & $\begin{array}{l}\text { Duodenal thickening still present, mucosal corrugation absent. } \\
\text { Duodenal and jejunal contents heavily admixed with mucus. }\end{array}$ \\
\hline & II & & Gross pathological lesions similar to Group I. \\
\hline & III & & $\begin{array}{l}\text { Duodenal thickening and mucosal corrugation absent. Duodenal and } \\
\text { jejunal contents watery and mixed with mucus. }\end{array}$ \\
\hline & $\mathrm{IV}^{*}$ & & No gross pathological lesions observed. \\
\hline
\end{tabular}

* Group IV cattle were uninfected control

TABLE 4 Histopathological lesions of the duodenum and jejunum from the different groups of cattle immunized and challenged with Calicophoron microbothrium

\begin{tabular}{|c|c|c|c|}
\hline Days post-challenge & Group & Intestinal site & Histopathological lesions \\
\hline \multirow{4}{*}{28} & I & \multirow{4}{*}{$\begin{array}{l}\text { Duodenum and } \\
\text { jejunum }\end{array}$} & $\begin{array}{l}\text { Brunner's glands hyperplastic, some cystic and occupy entire submu- } \\
\text { cosal area in some sections. Peyer's patches hyperplastic and } \\
\text { infiltrated by lymphoblastic lymphocytes. Subtotal villous atrophy } \\
\text { present in both the duodenum and jejunum. Goblet cells hyperplastic } \\
\text { with more than } 30 \text { cell per villous crypt unit. The lamina propria and the } \\
\text { submucosal areas heavily infiltrated by lymphocytes and plasma cells. } \\
\text { Fibrous tissue deposition in the lamina propria present. }\end{array}$ \\
\hline & ॥ & & Histopathological lesions similar to Group I. \\
\hline & III & & $\begin{array}{l}\text { Histopathological lesions similar to Group I but goblet cell numbers } \\
\text { between } 20 \text { and } 30 \text { per villous crypt unit. Infiltrations of lymphocytes } \\
\text { and plasma cells in the lamina propria and submucosal areas } \\
\text { drastically reduced. }\end{array}$ \\
\hline & $\mathrm{IV}^{*}$ & & No significant histopathological lesions were observed. \\
\hline \multirow{4}{*}{42} & I & \multirow{4}{*}{$\begin{array}{l}\text { Duodenum and } \\
\text { jejunum }\end{array}$} & $\begin{array}{l}\text { Histopathological lesions similar to Group I at Day } 28 \text { post-challenge } \\
\text { infection. Goblet cell numbers rose up to } 50 \text { per villous crypt unit. }\end{array}$ \\
\hline & II & & Histopathological lesions similar to Group I. \\
\hline & III & & $\begin{array}{l}\text { Histopathologyical lesions similar to group III at Day } 28 \text { post-challenge } \\
\text { infection. }\end{array}$ \\
\hline & $\mathrm{IV}^{*}$ & & No significant histopathological lesions were observed. \\
\hline
\end{tabular}

* Group IV cattle were uninfected controls 

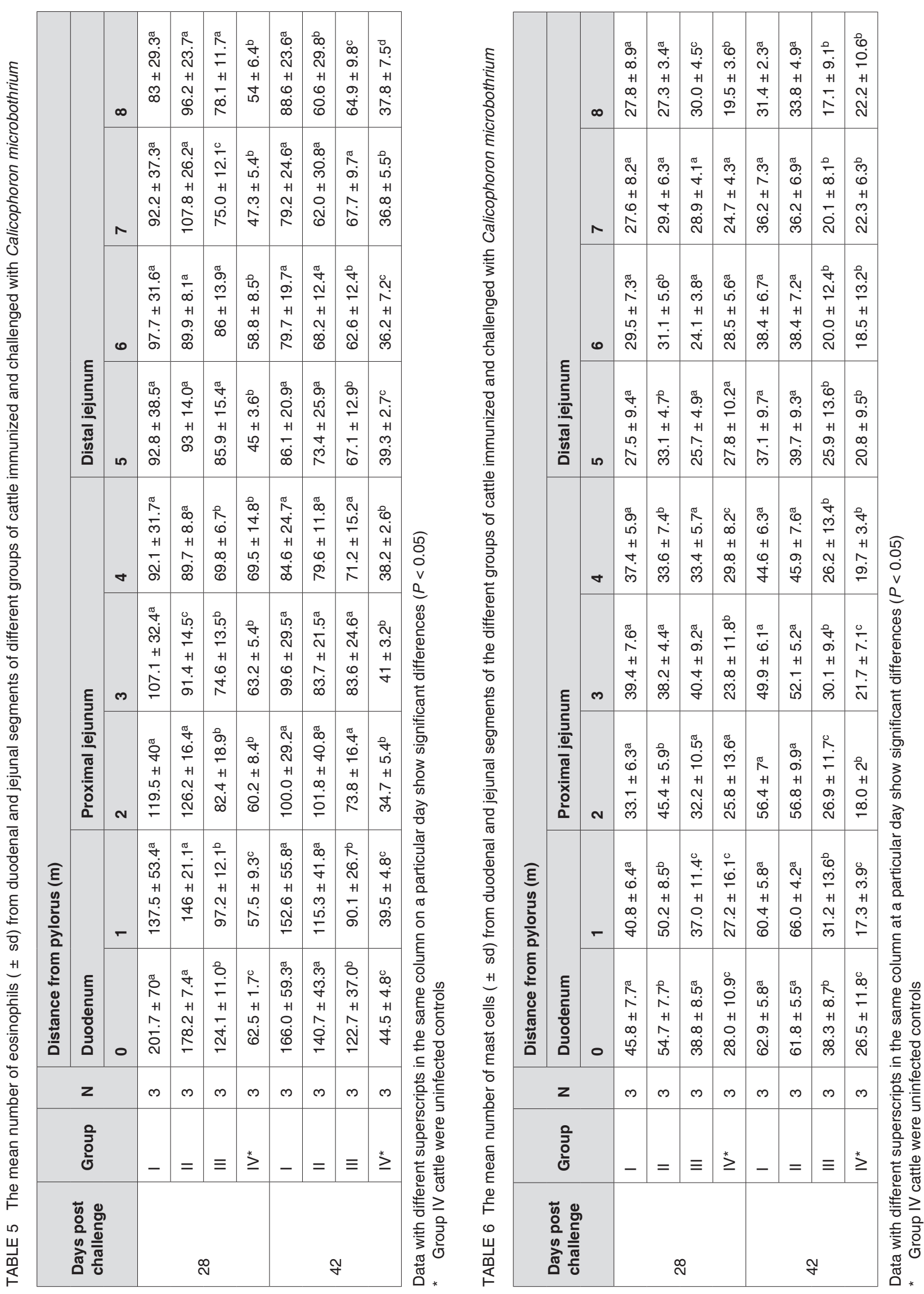
from Group II), which at slaughter harboured large numbers of mature amphistomes from the immunizing infection. The lesions included thinning, fragmentation and pale discoloration of the ruminal papillae, particularly at sites along the anterior pillar of the rumen where the flukes resided. In one animal from Group I in which $84 \%$ of the immunizing infection had established, complete destruction of the papillary tips along the anterior pillar, leaving short papillary stumps was observed. A few dead flukes were seen still attached to the ruminal papillae while surviving flukes were firmly attached to the base of the ruminal papillae.

\section{Histopathology of the small intestines and the rumen}

The histopathological lesions in the duodenum, jejunum and ileum of the different treatment groups are presented in Table 4. Villous atrophy, hyperplasia of the goblet cells and Brunner's glands, reactive Peyer's patches and pronounced fibrous tissue deposition were the predominant histopathological lesions noted among the infected groups. No histopathological lesions were observed in the mucosa of the duodenum and jejunum of the control animals slaughtered at the same time.

The histopathology of the rumen was characterized by cytogenic oedema of the stratum corneum, superficial micro-abscesses at the sites of attachment of the flukes and little cellular reaction at the dermalepidermal junction.

\section{Cytology}

The mean numbers of the various cell types from the different parts of the intestine of the immunized and challenged cattle are shown in Tables 5 and 6 .

\section{Eosinophils}

On Day 28 post-challenge infection, the mean numbers of eosinophils for Groups I and II were significantly higher $(P<0.05)$ than those in the control group at all intestinal sites (Table 5 ) but no significant differences in the mean eosinophil values were noted between the two infected groups at all intestinal sites except at level three of the proximal jejunum. In comparison with Group III animals, Groups I and II had significantly higher $(P<0.05)$ mean eosinophil values in the proximal jejunum and the duodenum but no significant differences could be detected in the distal jejunum among the 3 groups except at level seven. Generally Group III had significantly higher mean eosinophil values $(P<0.05)$ in the duodenum and the distal jejunum than the control group and no differences could be detected in the proximal jejunum of the two groups.

On Day 42 post-challenge infection, all the treated groups had significantly higher mean eosinophil values $(P<0.05)$ than the control group at all sites. No significant differences in mean eosinophil levels were detected between Groups I and II except at level eight of the distal jejunum. Group III had significantly lower mean eosinophil levels $(P<0.05)$ in the duodenum when compared to those in Groups I and II. No significant differences in mean eosinophil levels was detected at any other site among the 3 groups except at levels five, six and eight of the distal jejunum.

\section{Mast cells}

On Day 28 post-challenge infection, Groups I, II and III had significantly higher mean mast cell values $(P$ $<0.05$ ) in the duodenum and the proximal jejunum when compared to the control group and no significant differences could be detected in the distal jejunum among the four groups except at level eight of the distal jejunum (Table 6). Group II had significantly higher mean mast cell values $(P<0.05)$ in most sites of the duodenum and the proximal jejunum than Groups I and III.

On Day 42 post-challenge infection, Groups I and II had significantly higher mean mast cell values at all sites in comparison with those in Group III but no significant differences in the mean mast cell values could be detected between the two former groups at all sites. Group III had significantly higher mean mast cell values $(P<0.05)$ in the duodenum and first half of proximal jejunum than those in the control group but no significant differences could be detected in the distal jejunum.

\section{Globule leukocyte and basophils}

The levels of the mucosal globule leukocyte and basophil cell populations remained predominantly low in comparison to the levels of eosinophils and mast cell populations. Their activity also remained low in all the experimental groups on Day 42 post-challenge infection.

\section{DISCUSSION}

The resistance of cattle to amphistome re-infection has been demonstrated clinically (Horak 1967) but no simultaneous studies on the cellular effector sys- 
tems that characterize the acquired resistance were performed. The magnitude of the immunizing and challenge infections used in this study was adequate and was in accordance with prior observations that the two doses could induce pathological lesions and clinical disease in susceptible cattle. Similarly, the time intervals for the different experimental schedules in the present study were designed to allow the completion of the life-cycle of the immunizing infection in the host (Horak 1967) and regeneration of the gut mucosa from the pathological lesions it induced. The positive control group in the present study provided baseline data for comparing parasite establishment and the pathological effects of the challenge dose in the immunized groups, while the cattle were dewormed to establish whether a direct relationship existed between therapeutic removal of mature flukes from the rumen and a decrease in the host's immunity, as previously reported by Horak (1967).

In this study, all the experimental animals remained clinically normal during the study period. While the establishment rate of flukes in Group III was lower than expected, they caused the development of lesions in the intestinal mucosa and thus allowed an assessment of the cellular responses that characterize amphistome re-infection in cattle. The mean establishment rates in Group III were higher and caused more pathology than in the other two infected groups. This was expected since all the animals in this group were susceptible to infection. The immunizing infections used for Groups I and II had high establishment rates, which predictably immunized the host to re-infection. Consequently, the low establishment rate from the challenge infection in Groups I and II could be related to immunological rejection of the parasite.

The deworming of Group I animals was expected to eliminate the mature flukes from the immunizing infection and allow an assessment of the response of the intestinal mucosa to re-invasion, but the recovery of mature flukes from the rumen at the time of slaughter suggests therapeutic inefficiency. Efficacy studies so far conducted with the available drugs have failed to eliminate all mature flukes from the rumen (Boray 1969; Christopher 1974; Sinha 1975; Chhabra, Gill \& Dutt 1978; Dutt 1980; Panda \& Misra 1980; Rahman, Jagannath \& Souz 1985; Rolfe \& Boray 1987, 1993; Chaudhri 2000). The continued presence of the immunizing flukes in the rumen after a challenge infection seems to suggest that any induced anti-amphistome immune responses are likely to be directed against the immature stages of the parasite in the small intestines. Horak (1967) recovered immature flukes in voided faeces of challenged cattle and argued that the immune responses in reinfected cattle prevent fluke attachment and migration. While this argument could not be verified in this study, the presence of cystic duodenal glands of cattle in Groups I and II would suggest that the parasite still burrows into the Brunner's glands in amphistome challenged cattle.

The gross pathological lesions observed in Group I, II and III animals were similar to those described in goats and sheep (Horak \& Clark 1963; Rolfe et al. 1994) and could be the result of similar pathological mechanisms. The histopathological features, comprising goblet cell hyperplasia, reactive Peyer's patches, fibrous tissue deposition and moderate to heavy infiltrations of lymphocytes and plasma cells into the gastrointestinal mucosa of Groups I and II animals, were probably responsible for the thickening and hardening of the duodenal wall as seen macroscopically. While fibrosis and macrophage infiltrations have been reported to take part in delayed immunological reactions involving granulomatous reactions in some parasitic infections such as schistosomiasis (Techau 2002), the deposition of fibrous tissue and macrophage cell infiltration seen in this study were more likely related to the intestinal regenerative processes following the passage of the immunizing infection, as no parasite remnants could be detected in the intestinal mucosa to elicit a granulomatous inflammation at this stage of the study. Peyer's patches and the mesenteric lymph nodes constitute the local lymphoid system of the gut, which, if sensitised by the parasite antigens (Christensen 1991), would become hyperplastic in response to the activation of B-lymphocyte and plasma cells for antibody production (Tizard 1982; Christensen 1991). In this study the immunizing infection provided the primary stimulation which upon challenge led to the production of large numbers of lymphocytes and plasma cells seen histologically in the intestinal mucosa of Group I and II animals. The activated lymphocytes and plasma cells through a cascade of immunological reactions involving cytokine production and antibody synthesis stimulate the production and activation of effector cells including eosinophils, mast cells and globule leukocytes that destroy and evacuate parasites (Butterworth 1984; Miller 1984; Jain 1993; Jones 1993; Grencis 1997; Ovington \& Behm 1997; Rainbird, Macmillan \& Meeusen 1998).

Significantly higher values of mucosal eosinophils and mast cells were recorded in animals in Groups 
I and II when compared to Group III and it is probably related to prior sensitization of the immune system by the immunizing infection. Mucosal eosinophilia and mastocytosis have been described as common features in gastrointestinal helminthosis (Miller 1984; Huntley et al. 1984; Huntley 1992; Ovington \& Behm 1997; Rainbird et al. 1998). Their mechanisms of action involve degranulation and release of potent helminthicidal products such as major basic protein, eosinophilic cationic protein, eosinophil-derived neurotoxin, eosinophil peroxidase and toxic oxygen-derived metabolites by the eosinophils and slow reactive substance of anaphylaxis by the mast cells (McLaren, McKean, Olsson, Venge \& Kay 1981; Tizard 1982; Butterworth 1984; Lee, Swieter \& Befus 1986; Jain 1993; Jones 1993; Behm \& Ovington 2000; Falcone, Pritchard \& Gibbs 2001). In this study, the gross pathology of the small intestines in Groups I and II was characterized by increased fluidity of the contents. It is highly likely that the increased fluidity is related to the increased activity of the mast cells whose mechanism of action has been shown to cause increased intestinal permeability and thus flooding of the gastrointestinal tract to assist the expulsion of the parasite (Tizard 1982; Falcone et al. 2001).

Marginal increases in the number of globule leukocytes and basophils in the intestinal mucosa were recorded in this study. The globule leukocyte is regarded as a prominent cell in parasite resistance development particularly in sheep (Douch \& Morum 1993; Stankiewicz et al. 1993; Rolfe et al. 1994; Pfeffer et al. 1996) while basophils are prominent cells in guinea pigs infected with Trichostrongylus colubriformis (Rothwell \& Dineen 1972; Rothwell \& Love 1975). In this study the globule leukocytes occurred in low numbers even in the experimental groups which had received both the immunizing and the challenge infection. While the occurrence of globule leukocytes in sheep has been linked to genetic inheritance (Stankiewicz et al. 1993) and globule leukocyte trait positive sires can be used for breeding to produce parasite adapted flocks, the results of this study seem to suggest that the globule leukocyte might not be an important cell in cattle.

This study has demonstrated that cattle appear to acquire resistance to amphistome infection, which involves the accumulation of mucosal eosinophils and mastocytes. The resistance against amphistome re-infection in cattle seems targeted at immature flukes in the duodenum and the finding of dead mature flukes in the rumen after challenge infection suggests immunological mechanisms directed at this stage in the life cycle as well.

\section{ACKNOWLEDGEMENTS}

DANIDA through the ENRECA Livestock Helminth Research Project is acknowledged for the funding. Our thanks also go to all support staff in the Department of Paraclinical Veterinary Studies, University of Zimbabwe, for their assistance with collection of the samples, the staff in the histology laboratory of the Central Veterinary Laboratory for assisting with the processing of samples and Ms T. Munyombwe for her assistance with the analysis of the data.

\section{REFERENCES}

ANONYMOUS 1986. Manual of veterinary parasitological laboratory techniques. London: Her Majesty's Stationery Office.

BEHM, C.A. \& OVINGTON, K.S. 2000. The role of eosinophils in parasitic helminth infections: Insights from genetically modified mice. Parasitology Today, 16:202-209.

BORAY, J.C. 1969. Studies on intestinal paramphistomosis in sheep due to Paramphistomum ichikawai Fukui, 1922. Veterinary Medical Review, 4:290-308.

BORAY, J.C. 1985. Flukes of domestic animals: Paramphistomata, in World animal science, disciplinary approach. Vol. B2. Parasites, pests and predators, edited by S.M. Gafaar, W.E. Howard \& R.E Marsh. Amsterdam: Elsevier.

BUTLER, R.W. \& YEOMAN, G.H. 1962. Acute intestinal paramphistomiasis in Zebu cattle in Tanganyika. Veterinary Record, 74:227-231.

BUTTERWORTH, A.E. 1984. Cell-mediated damage to helminths. Advances in Parasitology, 23:143-235.

CHAUDHRI, S. 2000. Reduced responsivenesscof oxyclozanide and tetramisole hydrochloride combinations to gastrointestinal parasites of sheep. Indian Journal of Animal Science, 70: 396-398.

CHERUIYOT, H.K. \& WAMAE, L.W. 1988. Incidence of bovine paramphistomiasis in Kenya. Bulletin of Animal Health and Production in Africa, 36:55-57.

CHHABRA, R.G., GILL, B.S. \& DUTT, S.C. 1978. Paramphistomiasis of sheep and goats in the Punjab State and its treatment. Indian Journal of Parasitology, 2:43-45.

CHRISTENSEN, C.M. 1991. Studies of the immune response in cattle infected with normal or inhibited larvae of Ostertagia ostertagi (Trichostrongylidae). Ph.D. thesis. The Royal Veterinary and Agricultural University.

CHRISTOPHER, J. 1974. Zanil (oxyclozanide) in the treatment of amphistomiasis in sheep. Indian Journal of Animal Research, 8:79-80.

DEORANI, S.V.P. \& KATIYAR, R.D. 1967. Studies on the pathogenicity due to immature amphistomes among sheep and goats. Indian Veterinary Journal, 44:199-205.

DOUCH, P.G.C. \& MORUM, P.E. 1993. The effect of age on the response of Romney sheep to gastrointestinal nematodes during grazing. International Journal for Parasitology, 23: 651-655.

DUTT, S.C. 1980. Paramphistomes and paramphistomiasis in domestic ruminants in India, edited by A. Singh. Ludhiana: Punjab Agricultural University Press.

EDUARDO, S.L. 1983. The taxonomy of the family Paramphistomidae Fischoeder, 1901 with special reference to the mor- 
phology of the species occurring in ruminants. III. Revision of the genus Calicophoron Nasmark, 1937. Systematic Parasitology, 5:25-79.

FALCONE, F.H., PRITCHARD, D.I. \& GIBBS, B.F. 2001. Do basophils play a role in immunity against parasites? Trends in Parasitology, 17:126-126.

GRENCIS, R.K. 1997. Enteric helminth infection: Immunopathology and resistance during intestinal nematode infection. Chemical Immunology, 66:41-61.

GUPTA, N.K. 1993. Amphistomes, systematics and biology. New Dehli: Oxford and IBH Publishing Co.

HORAK, I.G. \& CLARK, R. 1963. Studies on Paramphistomiasis. $\mathrm{V}$. The pathological physiology of the acute disease in sheep. Journal of the South African Veterinary Medical Association, 30:145-160.

HORAK, I.G. 1965. Studies on paramphistomiasis. VII. The immunization of sheep, goats and cattle. Preliminary Report. Journal of the South African Veterinary Medical Association, 36:361-363.

HORAK, I.G. 1966. Studies on paramphistomiasis. VIII. The pathogenesis and symptoms of the disease in sheep. Journal of the South African Veterinary Medical Association, 37: 428-430.

HORAK, I.G. 1967. Host-parasite relationships of Paramphistomum microbothrium Fischoeder, 1901, in experimentally infested ruminants, with particular reference to sheep. Onderstepoort Journal of Veterinary Research, 34:451-540.

HORAK, I.G. 1971. Paramphistomiasis of domestic ruminants. Advances in Parasitology, 9:33-72.

HUNTLEY, J.F., NEWLANDS, G. \& MILLER, H.R.P. 1984. The isolation and characterization of globule leukocytes: their derivation from the mucosal mast cells in parasitised sheep. Parasite Immunology, 6:371-390.

HUNTLEY, J.F. 1992. Mast cells and basophils: A review of their heterogeneity and function. Journal of Comparative Pathology, 107:349-372.

HUNTLEY, J.F., PATTERSON, M., MACKELLAR, A., JACKSON, F., STEVENSON, L.M. \& COOP, R.L. 1995. A comparison of mast cell and eosinophil responses of sheep and goats to gastrointestinal nematode infections. Research in Veterinary Science, 58:5-10.

JAIN, N.C. 1993. Essentials of veterinary haematology. Philadelphia: Lea \& Febiger.

JONES, D.G. 1993. The eosinophil. Journal of Comparative Pathology, 108:317-335.

LEE, T.G.D., SWIETER, M. \& BEFUS, A.D. 1986. Mast cell response to helminth infection. Parasitology Today, 2:186-191.

MAVENYENGWA, M. 2004. Pathophysiology of Calicophoron microbothrium in experimentally infected cattle and the effect of a challenge infection. Ph.D. thesis. University of Zimbabwe.

MCLAREN, D.J., MCKEAN, J.R., OLSSON, I., VENGE, P. \& KAY, A.B. 1981. Morphological studies on the killing of schistosomula of Schistosoma mansoni by human eosinophil and cationic proteins in vitro. Parasite Immunology, 3:359-373.

MILLER, H.R.P. \& JARRETT, W.F.H. 1971. Immune reactions in mucous membranes I. Intestinal mast cell response during helminth expulsion in the rat. Immunology, 20:277-287.

MILLER, H.R.P. 1984. The protective mucosal response against gastrointestinal nematodes in ruminants and laboratory animals. Veterinary Immunology and Immunopathology, 6:167259.
MUKHERJEE, R.P. \& DEORANI, S.V.P. 1962. Massive infection of a sheep with amphistomes and the histopathology of the parasitised rumen. Indian Veterinary Journal, 39:668-670.

OVINGTON, K.S. \& BEHM, C.A. 1997. The enigmatic eosinophil: Investigation of the biological role of eosinophils in parasitic helminth infection. Memórias do Instituto Oswaldo Cruz, 92: 93-104.

PANDA, B.K. \& MISRA, S.C. 1980. Observations on the aetiology, clinical pathology and chemotherapy of immature amphistomiasis in buffalo calves. Indian Journal of Animal Health, 19:131-135.

PFEFFER, A., DOUCH, P.G.C., SHAW, R.J., GATEHOUSE, T.K., RABEL, B., GREEN, R.S., SHIRER, C.L., JONAS, W.E. \& BISSET, S. 1996. Sequential cellular and humoral responses in the abomasal mucosa and blood of Romney sheep dosed with Trichostrongylus axei. International Journal for Parasitology, 26:765-773.

PILLAI, U.N. \& ALIKUTTY, K.M. 1995. Clinico-hematological observation in bovine amphistomiasis. Indian Journal of Veterinary Medicine, 15:38-39.

RAHMAN, A., JAGANNATH, S. \& SOUZ, P.D. 1985. Anthelmintic activity of niclosamide in sheep and goats. Livestock Advisor, 10:47-49.

RAINBIRD, M.A., MACMILLAN, D. \& MEEUSEN, E.N.T. 1998. Eosinophil mediated killing of Haemonchus contortus larvae: effect of eosinophil activation and role of antibody, compliment and interleukin-5. Parasite Immunology, 20:93-103.

ROLFE, P.F. \& BORAY, J.C. 1987. Chemotherapy of paramphistomosis in cattle. Australian Veterinary Journal, 64:328.

ROLFE, F., BORAY, J.C., NICHOLS, P. \& COLLINS, G.H. 1991. Epidemiology of paramphistomosis in cattle. International Journal for Parasitology, 21:813-819.

ROLFE, P.F. \& BORAY, J.C. 1993. Comparative efficacy of moxidectin, an ivermectin/clorsulon combination and closantel against immature paramphistomes in cattle. Australian Veterinary Journal, 70:265-266.

ROLFE, F., BORAY, J.C., COLLINS, G.H. 1994. Pathology of infection with Paramhistomum ichikawai in sheep. International Journal for Parasitology, 24:995-1004.

ROTHWELL, T.L.W. \& DINEEN, J.K. 1972. Cellular reactions in guinea-pigs following primary and challenge infection with Trichostrongylus colubriformis with special reference to the roles played by eosinophils and basophils in rejection of the parasite. Immunology, 22:733-745.

ROTHWELL, T.L.W. \& LOVE, R.J. 1975. Studies of the response of basophil and eosinophil leukocytes and mast cells to the nematode Trichostrongylus colubriformis. II Changes in cell numbers following infection of thymectomised and adoptively or passively immunized guinea pigs. Journal of Pathology, 116:183-194.

ROTHWELL, T.L.W., WINDON, R.G., HORSBURGH, B.A. \& ANDERSON, B.H. 1993. Relationship between eosinophilia and responsiveness to infection with Trichostrongylus colubriformis in sheep. International Journal for Parasitology, 23:203-211.

SINGH, C.D.N. \& LAKRA, P. 1971. Pathologic changes in naturally occurring Cotylophoron cotylophorum infection in cattle. American Journal of Veterinary Research, 32:659-663.

SINHA, B.K. 1975. Efficacy of resorantel (Terenol) against paramphistomiasis in goats and calves. Current Science, 44: 526. 
Bovine intestinal cellular responses following infections with Calicophoron microbothrium metacercariae

STANKIEWICZ, M., JONAS, W.E., DOUCH, P.C.G., RABEL, B., BISSET, S. \& CABAJ, W. 1993. Globule leukocytes in the lumen of the small intestine and the resistance status of sheep infected with parasitic nematodes. Journal of Parasitology, 79:940-945.

TECHAU, M.E. 2002. Characterisation of the humoral immune responses in pigs congenitally or postnatally exposed to Schistosoma japonicum. M.Sc. thesis. University of Copenhagen.
TIZARD, I.R. 1982. An introduction to veterinary immunology, $2^{\text {nd }}$ ed. Philadelphia: Saunders Co.

URVASHI, H.S.B. \& KUAR, A. 2000. Immunization of lambs and kids with gamma irradiated amphistome metacercariae. Indian Veterinary Journal, 77:13-15.

WINTER, M.D., WRIGHT, C. \& LEE, D.L. 1997. The mast cell and eosinophil response of young lambs to a primary infection with Nematodirus battus. Parasitology, 114:189-193. 